\title{
Radiocarbon Dates, Climatic Events, and Social Dynamics during the Early Neolithic in Mediterranean Iberia
}

Author group with affiliation:

JQI_QUATINT-D-15-00332 To be published in: Quaternary International: Radiocarbon Dates, Climatic Events, and Social Dynamics during the Early Neolithic in

Mediterranean Iberia

Joan Bernabeu Aubán. Departament de Prehistòria i Arqueologia. Universitat de València, (Spain).

juan.bernabeu@uv.es

Oreto García Puchol (corresponding author). Departament de Prehistòria i Arqueologia. Universitat de València, (Spain).

oreto.garcia@uv.es

Michael Barton. School of Human Evolution \& Social Change. Center for Social

Dynamics \& Complexity. Arizona State University, (USA)

Michael.barton@asu.edu

Sarah McClure

Department of Anthropology. Pennsylvania State University (USA).

Sbm19@psu.edu

Salvador Pardo Gordó

Departament de Prehistoria i Arqueologia. Universitat de València, (Spain).

Salvador.pardo@uv.es 


\section{Abstract}

Our goal in this paper is to examine the socioecological dynamics of the Early Neolithic period in Iberia in order to test the usefulness of temporal probability curves built from dated sites as a relative proxy for exploring possible links between trends in population patterns and climatic fluctuations. We compare the information for the entire Iberian Peninsula with four Mediterranean regions, investigating the climate-population relationships that emerge when we zoom into particular regions. We evaluate climatic and other possible causes of similarities in the shapes of temporal probability curves across the Peninsula, associated with demographic changes in the early Neolithic sequence. Changes in subsistence patterns identified in empirical data from sites like Cendres cave (Alicante province), together with computational modeling that simulates long-term socio-ecological processes, suggest key variables that can help account for local dynamics. Theoretical approaches from Complex System Theory and Evolutionary Archaeology can help us to better understand evolutionary processes including the spread of farming.

Keywords: Socioecology, ${ }^{14} \mathrm{C}$, Climatic events, Early Neolithic, Mediterranean Iberia

\section{Introduction}

Research on European Neolithic sequences has underlined the potential of both global exogenic (mainly climatic Holocene events) and/or endogenic forces behind major changes in social evolutionary processes. Authors such as Gronenborn $(2009,2010)$ have focused on the role of climatic fluctuations detected in the Holocene marine and terrestrial climate records for the spread of farming from the Near East to Europe at a supra-regional level. He also emphasizes the need to zoom in to compare chronologies of local and regional fine- resolution data. Shennan et al. (2013) calculated summed ${ }^{14} \mathrm{C}$ probability densities from multiple sites at pan-European and regional scales as a relative demographic proxy to be compared with other general and fine-resolution climatic proxies. Both authors agree about the importance of carefully examining the relationships between particular abrupt climatic fluctuations and shifts in cultural sequences that occur at roughly the same time. Specifically the chronology for the end of the Early Neolithic in Central Europe (LBK) is used to explore alternative hypotheses related to the effects of climatic events (7.1k event $-5 b$ IRD event) (Gronenborn, 2009) or endogenous drivers (Shennan, 2013, Shennan et al., 2013) on social change. Shennan et al. (2013) take a more expansive geographic perspective in recent work that examines radiocarbon probability curves as demographic proxies for the entirety of Western Europe excluding 
southern regions (Iberia and Italy). These authors identify a general pattern of a population boom coincident with the arrival of food production economies, followed by a rapid decline some centuries later in multiple European regions. Comparing these population proxies with paleoclimate proxies of the middle Holocene, they conclude that fluctuations in population densities were not directly linked with the main climatic events. Instead, they propose that endogenous causes are more probable for these patterns in evolutionary socioeconomic processes at the beginning of the Neolithic period, perhaps related to a rapid population increase that lead to unsustainable levels, or other hypothetical internal causes (Shennan et al., 2013).

Recently, we tried to analyze similar relationships between relative Summed Calibrated Data Probability Distribution (SCDPD) of radiocarbon dates and climatic events in Iberia (Bernabeu et al., 2014). We examined its utility to observe trends in population dynamics for the Iberian Peninsula at a general scale, and within several sub-regions. We also compared demographic patterns with global and regional climatic proxies. As with the patterns reported by Shennan and colleagues from other areas of Europe, our analyses indicate a population boom that emerged after the arrival of the Neolithic in Iberia around 7650 cal BP, followed by a bust coincident with the end of the Early Neolithic sequences (Impressed Ware Culture) following the end of the VIII millennium cal BP. Additionally, we concluded that despite a general correspondence between climatic events at 8.2 and $7.1 \mathrm{cal} \mathrm{BP}$ (5a and 5b IRD events) and fluctuations in SCDPD, important discrepancies appear when we zoom into regional and local scales. In this paper, we take a longerterm perspective of socio-ecological changes by extending SCDPD from the Mesolithic to the Middle Neolithic. This allows us to examine the demographic trends of the Neolithic in the context of the longer history of human settlement in Iberia by focusing particularly on the Mediterranean zone of the Iberian Peninsula.

\section{Regional Setting}

The Iberian Peninsula, around $580.000 \mathrm{~km}^{2}$ in area, includes two main bioclimatic regions characterized by continental and Mediterranean ecological conditions respectively. This creates a mosaic of diverse ecosystems depending on altitude, latitude, and the distance to the sea. Since the beginning of the Holocene, progressive climatic amelioration has been reflected in the palynological and charcoal records (Carrión et al., 2010). The warmer and wetter conditions at the beginning of the Holocene are indicated by the increase of deciduous forest (oak) and the upward migration of conifers (pinus $s p$ and juniperus $s p$ ). The Mediterranean area of Iberia is traversed by two main corridors, the Mediterranean Sea and the Ebro river, that facilitated human interaction and social networks as seen in similarities in prehistoric artifact assemblages.

The Mesolithic precursors to the Neolithic appear in the material culture as a regional manifestation 
of the broader Castelnovian Tradition, characterized by the microblade geometric microlithic technology with trapezes that appeared in the first half of the IX millennium cal BP (Utrilla and Montes, 2009). Several centuries later, at the beginning of the VIII millennium cal BP, triangles began to dominate the geometric microlith assemblages.

The first domesticates in Iberia appear in the early Neolithic around $7650 \mathrm{cal}$ BP at sites located in core areas such as the Llobregat valley in Catalonia (Guixeres de Vilobí: OxA26068, 6655, 45 and El Cavet: OxA26061, 6536, 36 -Oms et al., 2014-), and Southern Valencia region (Cova d’En Pardo: Beta231880, 6660, 40 -García Atienzar, 2009-, Cova de les Cendres: Beta239377, 6510,40 Bernabeu and Molina, 2009-, Barranquet: Beta221431, 6510, 50 -Bernabeu et al., 2009-, Cova de 1'Or -UCIAMS66316, 6475, 25 -Martí, 2011-, Mas d’Is: Beta162092, 6600, 50 and Beta166727, 6600, 50 -Bernabeu, 2006-, Sarsa: OxA26076, 6506, 32 -García Borja et al., 2012, Falguera: 6510, 80 -García Puchol et al., 2009-), in addition to other inland sites as Chaves in the Ebro valley (GrA38022, 6580, 35 -Baldellou, 2012-) or Carigüela in Eastern Andalusia (Col1565, 6749, 39 Mednev, 2013-.) Belonging to the impressed ware cultural complex, the early Neolithic presents common material characteristics throughout western Mediterranean region. The rapid spread of the Neolithic way of life, documented by direct radiocarbon dates of domestic species, has been attributed to a process of maritime pioneer colonization (Zilhao, 2001). A mixed model that combines endogenous expansion of farming groups with a still poorly understood contribution of local hunter-gatherer groups is the most widely accepted hypothesis for Neolithic dispersals inland (see García Puchol et al., 2009, Juan Cabanilles and García Puchol, 2013, Bernabeu and Martí, 2014). In recent years, new archaeological discoveries have added data that connect some stylistic aspects of initial Neolithic ceramics with southern France and Ligurian impressed pottery (e.g., Barranquet and Mas d'Is, located in Valencia region -Bernabeu et al., 2009).

\section{Material and Methods}

Following protocols established in previous studies (Gamble, 2005, Shennan et al., 2013, Timpson et al., 2014), we calculated SCDPD curves as a relative demographic proxy to observe long-term trends in population. Williams (2012) notes several problems that potentially affect the validity of this method, based on the assumption that the number of archaeological sites can be linked to the number of available radiocarbon dates; and that a sufficiently large number of dates can mitigate biasing effects in the samples. He suggests filtering the radiocarbon dates to use in this way by excluding those with large standard deviations (SD) in order to reduce some of these problems. In the aforementioned paper (Bernabeu et al., 2014), we compiled all radiocarbon dates for Iberia, except for those in the northwestern regions of Cantabria and Galicia. In this contribution we have extended the compilation of radiocarbon dates to the entire Iberian Peninsula, and temporally from 
the beginning of the IX millennium until the end of the VII millennium cal BP with the goal of obtaining a broader chronological perspective. This dataset, compiled from published works and other publically-available radiocarbon data (Juan Cabanilles and Martí, 2002, Bernabeu, 2006, Carvalho, 2008; Catalunya C14, Rojo et al., 2012, Fano et al., 2014), contains 1271 radiocarbon dates between 8000 and 5000 bp. Table 1 details the radiocarbon dates classified by materials and regions. For calculating SCDPD curves, we only use radiocarbon dates with a standar deviation $\leq$ 200, and exclude dates on shell due to potential problems related to the marine reservoir effect (Ascough et al., 2005). Nonetheless, this filtered dataset includes a large number of dates, covering the entire Iberian Peninsula, and is comparable to other recently published work (Balsera et al., 2015).

An aspect of this approach that has been criticized is that bias can be introduced by variability in the number of dates for each site, together with differences in the research interests of archaeologists by region, as well as the different visibility of sites and structures (Crombé and Robinson, 2014). In recent work, several kinds of correction factors have been introduced in order to mitigate this bias through combining dates from a single site according to different criteria (Shennan et al., 2013, Balsera et al., 2015). While this approach can moderate this particular kind of error, it also can introduce other biases relating to the criteria used for combining dates from a site. Consequently, we decided to use an alternative method that filters dates by site and combines them at intervals of 50 years. First we calibrated all dates in Oxcal 4.2 (Bronk Ramsey, 2009) using the Intcal curve 2013 (Reimer et al., 2013), and then we distribute the dates ( 2 sigma range) by the 50-year temporal interval. This results in an average SD of 65.8, which is acceptable according to criteria proposed by Williams (2012), and a final number of 1108 dates for calculating SCDPD curves.

The distributions obtained correspond well with the number of sites dated by interval and serve as another proxy to illustrate diachronic trends in population dynamics. This also can help assess whether or not the SCDPD curves suffer from any of the problems referred to previously (Crombé and Robinson, 2014, Wood, 2015). We generated probability distributions curves and site count curves for the Iberian Peninsula and four regions of Mediterranean Spain in the broad sense (including Ebro Valley): Catalonia to the Ebro river (Northeast region), the upper and middle Ebro Valley, the eastern region (south of Ebro river to Júcar basin), and the east/southeast region (south of Júcar basin to Eastern Andalusia; Figure 1).

In order to better compare results from different regions and the entire peninsula, we converted the results to standardized Z-score values. As shown in Figure 2, both the SCDPD (Zdates) and site number (Zsites) curves are very similar. However, the site frequency curve does not show the same range of Z-scores, suggesting that some sites are overrepresented with respect to the number of dates obtained from them. This may be due, at least in part, to the special interest in archaeological 
research to date the beginning of the Neolithic. Hence, we use Zsites curves along with Zdates curves in other aspects of our analysis.

In order to evaluate possible climatic impacts on socioecological dynamics we used a well-known global paleoclimate proxy, the GISP2 ice core (Grootes et al., 1993, Meese et al., 1997), along with several well dated local proxies: the $\delta^{18} \mathrm{O}$ curve based on the G. bulloides record from core MD992343 in the Balearic sea (Frigola et al., 2007); and core MD952043 that shows the variation in surface temperature in the Alboran sea (Cacho et al., 1999). Different information and resolution is visible from these proxies that help to identify local manifestations of global episodes such as the 8.2 and $7.1 \mathrm{ka}$ coldest and driest events. These episodes coincide with $5 \mathrm{a}$ and $5 \mathrm{~b}$ Holocene IRD events that correspond with iceberg discharges that supplied fresh water to the North Atlantic.

Holocene climate fluctuations are unequally represented in the terrestrial and marine records (Cacho et al., 1999). The clearest signal is associated with the MD952043 Alboran Sea core, where a decrease in surface temperature of $1 \mathrm{C}^{\circ}$ is associated with the 8.2 event (Cacho et al., 1999). Cortés et al. (2012) have claimed that, a climatic and environmental crisis reflected in the decrease of marine productivity in southern Iberia is visible in the following centuries (between 8 and 7.3 cal $\mathrm{BP})$, affecting the last hunter-gatherer populations who quickly became farmers.

In the MD99-2343 core of Menorca, Frigola and colleagues (2007) identified nine $\delta^{18} \mathrm{O}$ enrichment events that are related to colder surface conditions. These oscillations coincide with the North Atlantic episodes. The coldest event is M8, spanning 9000-7800 cal BP, and involving the $8.2 \mathrm{ka}$ event (Frigola et al., 2007). The M7 event shows another colder oscillation that can be linked with the 7.1 ka event. In summary, global patterns of climatic fluctuations can be observed in several local proxies, particularly marine proxies, but the variability in their impacts requires better local resolution in order to compare the direct effects on socioecological dynamics in Iberia (Bernabeu et al., 2014).

\section{Results}

Figure 3 shows the SCDPD curve for Iberia from the late Mesolithic through Middle Neolithic. Despite the use of a more extensive radiocarbon sample, we can observe trends similar to those in previous work (Bernabeu et al., 2014): a rise in the number of radiocarbon dates and dated sites coinciding with the most probable date for the Neolithic arrival, commonly placed around 76507600 cal BP, followed by a fall at the end of VIII millennium. Can we relate this changing pattern with any climatic event? While there is no clear relationship between the initial Neolithic growth of the curve and any climatic event at the scale of Iberia, there is an approximate match between the fall of the dating curve, and the event at $7.1 \mathrm{ka}$. We explore this co-occurrence at greater regional detail, focusing on Mediterranean Spain. 


\subsection{Regional variability}

Figure 4 shows the curves for each of the four previously described regions of Mediterranean Iberia, along with the standardized values for dated sites. Although the four regions present similar general trends there are some interesting particularities. The common pattern consists of the sharp increase related to the appearance of domestic economies in the four areas followed by a drop in radiocarbon dated sites some centuries later. This type of rise/fall cycle is visible among all the regional sequences plotted, but the one related to the beginning of the Neolithic is sharper. Nevertheless there are regional differences in the timing and shape of these cycles.

The curves of NE (158 dates from 58 sites) and ESE (114 dates from 28 sites) regions are similar except for the Mesolithic period (Figure 4); in both regions radiocarbon dates of domestic resources indicate a similar chronology for the beginning of the Neolithic (c. 7650-7600 cal BP). Despite differences in the curve for the Mesolithic, mainly due to the absence of Late Mesolithic sites in the NE (Vaquero and García-Argüelles, 2009), the rise of the curve associated with the first Neolithic is equally marked in both regions. What looks different is the fall-off pattern after the initial Neolithic that is much less pronounced in the NE than in the ESE region. Finally, there is a second rise and fall pattern that is associated with the Middle Neolithic on both regions.

The Ebro valley curve (186 dates from 34 sites) shows a less pronounced rise starting around c. $7500 \mathrm{cal}$ BP that can be explained by the documentation of numerous late Mesolithic sites dating to the first half of the VII millennium cal BP (Figure 4). The fall-off is visible after 7000 cal BP, with a much steeper decline than in all other regions. The East region displays a curve similar to the Ebro valley (Figure 4), but is based on a smaller sample (75 dates from 18 sites). If it is not an effect of the small sample, the interpretations are similar in both cases with an initial rise during the earliest Neolithic. In contrast, the decline of the curve is pronounced in both regions, and shows no rise associated with Middle Neolithic visible in NE and SE.

Interestingly, there are significant cultural transformations in all these regions that coincide with the drop in the Neolithic radiocarbon dates. During the period of initial growth (c.7450-7150 cal BP), Neolithic villages were established and organized the new territories that included cave sites, hunting grounds, and rock art sanctuaries. Pottery styles define two major areas: the Cardial around the coast and the Epicardial inland (Ebro valley). This suggests the development of geographically extensive social networks within which information and commodities flowed, affecting extensive regions at different scales and intensity. However, from the end of VIII millennium cal BP, pottery styles became more regional, indicating a fragmentation of previously established networks.

In summary, it seems clear that:

a) There is a recurrent pattern of demographic rise-and-fall during the Neolithic in all regions. This Early Neolithic demographic event (c. 7600-6900 cal BP) is similar to that described in other parts 
of Europe (Gronenborn, 2009, Shennan et al., 2013).

b) At the scale of Iberia, there is a broader co-occurance of global climatic events (in the case the $7.1 \mathrm{ka}$ event) and the observed decline in the Neolithic radiocarbon dates, as noted earlier (Bernabeu et al, 2014) and supported in another recent paper using a broader radiocarbon data set (Balsera et al., 2015).

c) However, the timing, size and slope of the curve differs between regions. In other words, if there are climatic impacts on Neolithic settlement and subsistence, the effects are not the same across the regions analyzed here.

In short, climatic events affected human societies, but the consequences were regionally variable. This variation could be due to differences reflecting the importance of biotic factors and human economic behavior, especially land use. Since both factors -ecology and human behavior- are historically contingent, it would be surprising to find the same effects everywhere. Assuming this, it seems clear that what we need are not only new, high-quality proxy records both of human and environmental conditions, but a way to understand how different local dynamics could result in global patterns of change.

\section{Discussion}

Other possible drivers than help us to understand the regional diversity need to be explored. The dynamics of landuse-landscape interactions of agricultural communities over generations at the local scale at which human decisions took place seems to be a good avenue for study.

\subsection{A socio-ecological perspective}

Recent research (Barton et al., 2010, 2012) has shown that modeling the dynamics of landuselandscape interactions of agricultural communities over generations could help us to better understand the process underlying the population decline of early Neolithic societies. We focus specifically on the ESE region, one of the most intensively studied areas for the Neolithic transition in Iberia (Garcia Puchol, 2005, Fernández and Gómez, 2009, García Atienzar 2009, Bernabeu et al, 2012). Within this area, the Serpis Valleys is a small region (about $1.250 \mathrm{~km}^{2}$ ) that has been the focus of a collaborative research project for over two decades (Barton et al. 1999, 2002, 2004a, 2004b, Bernabeu et al. 1999, 2000, 2006, 2012, García et al. 2009, McClure, 2011, McClure et al. 2008, 2009)

A component of this work is the MedLand project, designed to carry out computational experiments on the long-term interactions between society, land-use, and environmental change (Barton et al. 2010a, b, 2012). Its results suggest that some kinds of agricultural practices could have a beneficial effect over small communities located at valley bottoms. However, as communities grow past a 
locally determined threshold size, the consequences of identical land-use practices change, with the potential for leaving a catchment unsuitable for farming.

One strategy to mitigate such environmental degradation is to reduce community size through emigration or fission. Another less obvious solution discovered in these experiments is to increase the amount of grazing relative to cultivation, in order to move the impacts of soil erosion. Conservation measures, like terracing, also could be instituted but we have no clear indicators about the existence of these practices during the Neolithic.

How could this kind of process have been responsible for the shifts described in the entire system? And how can we evaluate it? The answer to the first question relies on theoretical questions about how we can understand the processes of socio-economic changes. We will return to this question at the end of the text. First, we need to explore the possible archaeological indicators to assess whether the strategies specified in the model actually occurred in the same region where model was run.

5.2 Fission, migration and economic transformation

In the ESE region, the Serpis valley is the area where the first Neolithic settlers were established around c. 7600 cal BP (Bernabeu and Martí, 2014). Recent studies (García Atienzar, 2009, Jover et al., 2014) indicate that the occupation of the areas situated south of the Serpis valleys is more recent. The few available radiocarbon dates and the analysis of archaeological findings (mainly pottery decoration) suggest that a process of colonization of new areas by fission of early groups could have taken place from c. $7300 / 7200 \mathrm{cal}$ BP. It is unclear if it was simply a process resulting from community growth, or if it was fueled by the kind of negative feedback between agro-pastoral practices and the landscape suggested by the model. In any case, it should be noted that changes in settlement pattern begin to emerge in the Serpis valley after c. 7200 cal BP.

More interesting are the changes that took place in the subsistence system. Several authors emphasize that by mid-VII millennium cal BP, both agriculture (Pérez Jorda et al., 2013) and livestock (García Atienzar, 2006) underwent significant changes. In order to assess if there were substantial changes in pastoral activities and their timing, we look to shifts in specialized places in livestock management: the pens. In Mediterranean prehistory, these places were often caves used for sheltering livestock in small-scale migratory cycles and this practice continued until recently (Seguí, 1999). These sites provide opportunities to obtain better information about site functionality, and more specifically about the relative importance of changing strategies in herding.

Traditional approaches to identifying sheepfolds in cave deposits involve geo-archaeological methods to identify typical layers resulting from the continued use of certain places as livestock pens (Brochier et al., 1992). Moreover, ethnoarchaeological studies focusing on pastoralist campsites and associated material culture conclude that herders rarely leave much behind (Ammerman et al, 1978; Robertshaw, 1978). Combining these two approaches, we use the case of 
Cendres Cave to illustrate this issue.

\subsection{Cendres Cave}

Located near the shoreline at Cap de la Nau in Alicante province (Spain), Cendres cave is a large cavity with two accessible spaces: an outer area $(30$ by $25 \mathrm{~m})$ and an interior area (30 by $50 \mathrm{~m})$. Excavations were carried out from 1981 to 1991 in the interior, and have been published recently (Bernabeu and Molina, 2009). Throughout a 3.5m sequence, various overlapping levels reflect the changing occupation of the cave between the Early Neolithic and Bronze Age, ranging from c. 7500 cal BP to 3800 cal BP (Figure 5). This gives us the opportunity to observe the effect of occupation dynamics in the cave over a long period of time. The sequence has been divided in two main phases according to its presumed functionality. The lower occupation phase, dated from c. 7500-7000 cal BP, has been interpreted as a multifunctional site, a place where different activities took place.

The function of the cave changed after about c. $6900 \mathrm{cal}$ BP. This phase is interpreted as a livestock pen, resulting from the recurrent use of the cave to house flocks of sheep and goats. Domestic activities may have been conducted at the same time in other parts of the cave, as has been recently reported for the case of Cueva del Toro (Éguez et al., 2014). However, at Cendres cave, shift in use in the excavated areas is clearly evident by the coprolite distribution in the upper part of the sequence as shown in Figure 6. In this part, the stratigraphy is composed of a succession of ashy layers with a dark-brown base resulting from fires (Figure 5). These are known as "fumiers", layers formed as a result of the use of the cave as a corral. Other levels are sandwiched between them, formed as a result of the usual processes of stratification. Coprolites are found mainly in the former. Prior to layer H14 there is a possible single event, but two clusters of coprolite concentrations were observed: from layer H14 to layer H8; and from layer H4 to layer H1 (Figure 6). In the lower cluster, the coprolite concentration is spaced so that each episode of stabling is separated from the next by another level without residues. This is not the case with the second cluster that also has a higher density of coprolites.

These differences are likely the result of different livestock management factors (e.g. herding strategies, herd size, continuity, etc.). The important question for our purposes, however, is if we can determine the main function of a particular site. Of course, herders conduct different activities (e.g., using fireplaces, repairing pottery or making tools), and these may be not the same activities they practice in other, non-specialized places, nor in the same volume or intensity. These issues may be evaluated using the archaeological record.

In the Figure 6 we plot the density distributions of different kind of artifacts and resources discarded in Cendres cave, together with coprolite accumulations. It seems clear that the lower layers have a greater density of archaeological materials. From h14 upwards, when the cave becomes a corral, 
artifact density decreases dramatically, suggesting a reduction in activity.

This is the kind of pattern we expect to find associated with a specialized pen site. The radiocarbon dates place this change between c. 6900-6800 cal BP. Other caves, like Cova de l'Or show a similar pattern (Badal et al., 2012), but with a weaker resolution. In addition changes in other data have implications for settlement patterns (Bernabeu et al 2012). Shifts in subsistence and interaction networks suggest broad scale changes in the regional system, after 6500 BP. Similar transformations of cave use have been documented elsewhere in Mediterranean Iberia, such as at Cueva del Toro (Éguez et al., 2014 ), or Los Husos II (Fernández Eraso and Polo Díaz, 2008). This information supports the interpretation about the changing patterns of herding strategies suggested by the model, placing this transformation around the beginning of VII millennium cal BP.

\section{Conclusions}

Our aim in this work has been to analyze ways in which evolutionary processes were related to the Early Neolithic sequence in Iberia by combining information on population trends and data provided by local scenarios through virtual laboratories and the archaeological record. We use SCDPD curves as a relative proxy for prehistoric population trends (Shennan et al., 2013), enhancing this method through the use of standardized $\mathrm{Z}$ scores and comparisons with the number of sites dated with a series of the temporal intervals. The standardized SCDPD and site frequency curves are compared with global and local climatic proxies in order to evaluate possible relationships with climatic events. The Iberian data presented here mirrors the general pattern observed in other European Neolithic sequences with respect to a rise in population (coinciding with the arrival of food production economy) followed by a fall some centuries later (at the end of the Early Neolithic period). But when we observe the details by region, some variability in this general pattern emerges. The relationship between climatic events and the fluctuations in the SCDPD and site frequency curves show covariance at some times and in some regions, but also display important regional diversity.

The usefulness of the method in the future will require increasing the number of accurate ${ }^{14} \mathrm{C}$ dates, and comparisons with other archaeological proxies (Wood, 2015). Despite the possible impact of climatic events on prehistoric social and subsistence systems, it is necessary to investigate other internal factors to understand how local processes (sometimes acting together with climate and other times acting independently) can influence the emergence of properties that affect the entire system. The MEDLAND project provides hypotheses about the socio-ecological consequences of initial Neolithic settlement and land-use, and the study of the archaeological record from the Serpis Valley allows us to investigate the important changes detected at the end of the Early Neolithic. From current data, a new subsistence pattern with changes in livestock and agricultural practices 
has been proposed. As suggested (Bernabeu et al, 2014), these local shifts may have removed key groups from regional social networks, potentially resulting in the fragmentation of networks established earlier, limiting the information flow over the entire network, and then modifying the system at a global scale.

\section{Acknowledgments}

This work was supported by the research projects of government of Spain HAR2012-33111 "MESO COCINA: los últimos caza-recolectores y el paradigma de la neolitización en el mediterráneo peninsular". Collaborative research in eastern Spain and the Mediterranean Landscape Dynamics project were supported by National Science Foundation grants: BCS-0075292, BCS-0331583, BCS-0122866, BNS-9115209, SBR-9904050, BCS-410269, BCS-638879, BCS-543848, and DEB1313727.

\section{References}

Ammerman, A.J., Gifford, D.P., Voorrips, A., 1978. Towards an Evaluation of Sampling Strategies; Simulated Excavations of a Kenyan Pastoralist Site. In: Hodder, I. (Ed.), Simulation studies in Archaeology, Cambridge University Press, Cambridge: 123-132.

Ascough, P. Cook, G., Dugmore, A. 2005. Methodological Approaches to Determining the Marine Radiocarbon Reservoir Effect. Progress in Physical Geography 29 (4), 532-547.

Badal García, E., Martí Oliver, B., Pérez Ripoll, M., 2012. From agricultural to pastoral use: changes in neolithic landscape at Cova de l'Or (Alicante, Spain). Saguntum: Papeles del Laboratorio de Arqueología de Valencia, Extra 13, Universitat de València, 75-84.

Baldellou, V., 2012. La Cueva de Chaves (Bastarás-Casbas, Huesca). Saguntum: Papeles del Laboratorio de Arqueología de Valencia, Extra 12, 141-144.

Balsera, V., Díaz del Río, P., Gilman, A., Uriarte, A., Vicent, J.M., 2015. Approaching the demography of late prehistoric Iberia through summed calibrated date probability distributions (7000-2000 BC). Quaternary international, //dx.doi.org/10.1016/j.quaint.2015.06.022.

Barton, C. M. Bernabeu, J. Aura, J. E., Garcia Puchol, O., 1999. Landscape dynamics and socioeconomic change: an example from the Polop Alto valley. American Antiquity 64, 609-634. 
Barton, C.M. Bernabeu, J. Aura, J.E. Garcia, O., La Roca, N., 2002. Dynamic landscapes, artifact taphonomy, and landuse modeling in the western Mediterranean. Geoarchaeology ,17 (2), 155-190.

Barton, C.M. Bernabeu, J. Garcia, O. Schmich, S., Molina, L., 2004a. Long-term socioecology and contingent landscapes. Journal of Archaeological Method and Theory, 11(3), 253-295.

Barton, C.M. Bernabeu, J. Aura, J. E., Molina, L., 2004b. Historical contingency, nonlinearity, and the neolithization of the western Mediterranean. In: Wandsnider, L. and Athanassopoulos, E. (Eds.), Current Issues in Mediterranean Landscape Archaeology. Philadelphia: University of Pennsylvania Press, pp. 99-124.

Barton, C.M. Ullah, I.I.T., Bergin, S., 2010a. Land use, water and Mediterranean landscapes: modelling long-term dynamics of complex socio-ecological systems. Philosophical Transactions of the Royal Society: A Mathematical, Physical and Engineering Sciences 368, 5275-5297.

Barton, C.M. Ullah, I.I.T. Bergin, S.M. Mitasova, H., Sarjoughian, H., 2012. Looking for the future in the past: long-term change in socioecological systems. Ecological Modelling 241, 42-53.

Barton, C.M., Ullah, I., Mitasova, H., 2010b. Computational modeling and Neolithic socioecological dynamics: a case study from southwest Asia. American Antiquity 75, 364-86.

Bernabeu, J., 2006. Una Visión Actual Sobre El Origen y Difusión Del Neolítico En La Península Ibérica. In: García, O. and Aura, J.E (Eds.), El Abric de la Falguera (Alcoi, Alacant): 8.000 Años de Ocupación Humana en la cabecera Del río de Alcoi. Alcoi: Museu d'Alcoi, pp. 189-211.

Bernabeu, J., Barton, C.M, García Puchol, O., La Roca, N., 1999. Prospecciones sistemáticas en el valle del Alcoi (Alicante, España). Primeros resultados. Arqueología Espacial, 21, 29-64.

Bernabeu, J., Barton, C.M., García Puchol, O., La Roca, N., 2000. Systematic survey in Alicante, Spain. First results, Tüba-Ar III, 55-83.

Bernabeu Aubán, J.. García Puchol, O., Pardo Gordó, S. Barton, M., and McClure, S.B., 2014. Socioecological dynamics at the time of Neolithic transition in Iberia. Environmental Archaeology, 19 (3), 214-225. 
Bernabeu, J., Martí, B., 2014. The First Agricultural Groups in the Iberian Peninsula in Transitions in Mediterranean how hunters became Farmers. In: Manen, C., Perrin, T., Guilaine, J. (Eds.), The Neolithic transition in the Mediterranean, Errance, 419-438.

Bernabeu, J., Molina, L. (Eds.), 2009. La Cova de Les Cendres, Serie Mayor. Fundación MARQ, Alicante.

Bernabeu, J. Molina, LL. Esquembe, M.A. Ramón, J.,Boronat, J.D., 2009. La cerámica impresa mediterrána en el origen del Neolítico de la península Ibérica. In: De Méditerranée et d'ailleurs...Mélanges offerts à Jean Guilaine. Archives d’Écologie Préhistorique, pp. 83-95.

Bernabeu, J. Moreno, A., Barton, M.C., 2012. Complex systems, social networks and the evolution of social complexity. In: Berrocal, M.C. García Sanjuán, L., Gilman, A. (Eds.), The Prehistory of Iberia: Debating Early Social Stratification and the State. New York: Routledge, pp. 23-37.

Brochier, J.É., Villa, P., Giacomarra, M., 1992. Shepherds and sediments: geo-ethnoarchaoelogy of pastoral sites. Journal of Anthropological Archaeology, 11, 47-102.

Bronk Ramsey C. 2009. Bayesian analysis of radiocarbon dates. Radiocarbon 51(1), 337-60.

Cacho, I., Grimalt, J.O., Pelejero, C., Canals, M., Sierro, F.J., Flores, Abel Flores, J., Shackleton, N., 1999. Dansgaard-Oeschger and Heinrich event imprints in Alboran Sea paleotemperatures. Paleoceanography 14, 698-705.

Carrión, J.S. Fernández, S. González Sampériz, P. Gil Romera, G. Badal, E. Carrión Marco, Y. López-Merino, L. López Sáez, J.A. Fierro, E., Burjachs, F., 2010. Expected trends and surprises in the Lateglacial and Holocene vegetation history of the Iberian Peninsula and Balearic Islands. Review of Palaeobotany and Palynology 162, 458-475.

Carvalho, A. 2008. A Neolitização do Portugal Meridional: Os exemplos do Maciço Calcário Estremenho e do Algarve Ocidental. Promontoria Monográfica. Faro: Universidade do Algarbe.

Catalunya C14: http://www.telearchaeology.com/c14/metode_bibliografia.htm

Crombé, P., Robinson, E., 2014. 14C dates as demographic proxies in Neolithisation models of 
northwestern Europe: a critical assessment using Belgium and northeast France as a case-study. Journal of Archaeological Science, http://dx.doi.org/10.1016/j.jas.2014.02.001

Cortés, M., Jiménez, FJ., Simón, MD., Gibaja, JF., Faustino, A., Martinez-Ruiz, F., Rodrigo, M., Flores, JA., Paytan, A., López, JA., Peña-Chocarro, L., Carrión, JS., Morales, A., Roselló, E., Riquelme, JA., Dean, RM., Salgueiro, E., Martínez, RM., De La Rubia, JJ., Lozano, MC., Vera, JL., Llorente, L., Bicho, NF., 2012. The Mesolithic-Neolithic transition in southern Iberia. Quaternary Research 77 (2), 221-234.

Éguez, N., Mallol, C., Martín Socas, D., Camalich, M.D., 2014. Radiometric dates and micromorphological evidence for syncronous domestic activity and sheep penning in a Neolithic cave: Cueva de El Toro (Málaga, Antequera). Archaeological and Anthropological Sciences, DOI:10.1007/s12520-014-0217-0.

Fano, M.A., Cubas, M., Wood, R., 2014. The first farmer in Cantabrian Spain: Contribution of numerical chronology to understand an historical process. Quaternary International 364, 153-161.

Fernández Eraso. J., Polo Díaz, A., 2008-2009. Establos en abrigos bajo roca de la Prehistoria Reciente: su formación, caracterizacón y proceso de estudio. Los casos de Los Husos y de San Cristobal. KREI 10, 39-51.

Fernández Lopez de Pablo, J. and Gómez Puche, M. 2009. Climate change and population dynamics during the Late Mesolithic and the Neolithic transition in Iberia. Documenta Praehistorica XXXVI, 67-96.

Frigola, J. Moreno, A.; Cacho, I. Canals, M.; Sierro, F.J. Flores, J.A. Grimalt, J.O. Hodell, D.A., Curtis, J.H., 2007. Holocene climate variability in the western Mediterranean region from a deepwater sediment record. Paleoceanography 22, PA2209.

Gamble, C. Davies, W. Pettitt, P. Hazelwood, L., Richards, M., 2005. The Archaeological and Genetic Foundations of the European Population during the Late Glacial. Cambridge Archaeological Journal 15, 193-223.

García Atiénzar, G., 2006. Valles, cuevas y abrigos: el paisaje pastoril durante el Neolítico de las comarcas centromeridionales del País Valenciano. In: Grau, I., (Ed.), La Aplicación de los SIG en la Arqueología del Paisaje. Universidad de Alicante, pp. 149-170. 
García Atiénzar, G., 2009. Territorio neolítico : las primeras comunidades campesinas en la fachada oriental de la península Ibérica (ca. 5600-2800 cal BC). British Archaeological Reports, International Series. Archaeopress, Oxford, England.

García Borja, P., Salazar García, D., Martins, H., Pérez Jordà, G., Sanchís Serra, A., 2012. Dataciones radiocarbónicas de la Cova de la Sarsa (Bocairent, Valencia). Recerques del Museu d'Alcoi, 21, 19-24.

García Puchol, O. Molina Balaguer, Ll. Aura Tortosa, J.E., Bernabeu Aubán, J., 2009. From the Mesolithic to the Neolithic on the Mediterranean coast of the Iberian Peninsula. Global Action in human Context. Adapting to the Holocene in Iberia. Journal of Anthropological Research 65 (2), special issue, 237-251

García Puchol, O., 2005. El proceso de Neolitización en la fachada mediterránea de la península Ibérica. Tecnología y Tipología de la piedra tallada. British Archaeological Reports, 1430, Oxford.

Gronenborn, D. 2009. Climate fluctuations and trajectories to complexityin the Neolithic towards a theory. Documenta Praehistorica 36, 97-110.

Gronenborn, D. 2010. Climate, Crises, and the neolithisation of Central Europe between IRDevents 6 and 4. In: Gronenborn, D., Petrasch, J. (Eds.), The Spread of the Neolithic to central Europe. International Symposium, Maiz 24 June - 26 June 2005. Mainz: Verlag des RömischGermanischen Zentralmuseums, 61-81.

Grootes, P., M. Stuiver, J. W. C. White, S. J.Johnsen, Jouzel, J., 1993. Comparison of oxygen isotope records from the GISP2 and GRIP Greenland ice cores, Nature, 366, 552-554.

Jover Maestre, F.J., Torregrosa Giménez, P., García Atiénzar, G., (Eds.), 2014. El Neolítico en el Bajo Vinalopó (Alicante, España). British Archaeological Reports S2646, International Series. Archaeopress.

Juan Cabanilles, J., García Puchol, O., 2013. Rupture et continuité dans la néolithisation du versant méditerranéen de la péninsule Ibérique: mise à l'épreuve du modèle de dualité culturelle. In: Jaubert, J., N. Fourmen, N., Depaepe, P., (Eds), XXVIIe Congrès Préhistorique de France. 
Transitions, Ruptures et Continuité durant la Préhistoire/Transitions, Ruptures and Continuity in Prehistory. Bordeaux-Les Eyzies 31 mai-5 Juin., 405-417.

Juan Cabanilles, J., Martí, B., 2002. Poblamiento y procesos culturales en la península Ibérica del VII al V milenio ac., Saguntum: Papeles del Laboratorio de Arqueología de Valencia, Extra 5, 4587.

Martí, B., 2011. La Cova de 1’Or (Beniarrés, Alacant). Saguntum. Papeles del Laboratorio de Arqueología de Valencia, no extra 12: 183-186.

McClure, S.B., 2011. Learning Technology: Cultural Inheritance and Neolithic Pottery Production in the Alcoi Basin, Alicante, Spain. BAR, British Archaeological Reports 2300, Oxford.

McClure, S.B. Molina, LL., Bernabeu, J., 2008. Neolithic rock art in context: Landscape history and the transition to agriculture in Mediterranean Spain. Journal of Anthropological Archaeology 27, 326-337.

McClure, S.B. Barton, C.M., Jochim, M., 2009. Human behavioral ecology and climate change during the transition to agriculture in Valencia, eastern Spain. Journal of Anthropological Research $65,253-269$.

Meese, D. A., Gow, A.J., Alley, R.B., Zielinski, P-M., Grootes, G.A., Ram, M., Taylor, K.C., Mayewski, Bolzan, J.F., 1997. The Greenland Ice Sheet Project 2 depth-age scale: Methods and results. Journal of Geophysical Research,102, 411-423.

Medved, I. 2013. Continuty vs. Discontinuity. Epipaleolithic and Early Neolithic in the Southeast of the Iberian Peninsula. Ph. D. Cologne. kups.ub.uni-koeln.de/5217/1/Medved2013_Continuity.pdf

Olsen, J. Heinemeier, J., Bennike, P., Krause, C., Margrethe Hornstrup, K., Thrane, H., 2008. Characterisation and blind testing of radiocarbon dating of cremated bone. Journal of Archaeological Science 35, 791-800.

Oms, F.X., Esteve, X., Mestres, J., Martí, P., , and Martins, H., 2014. La neolitización del nordeste de la Península Ibérica: datos radiocarbónicos y culturales de los asentamientos al aire libre del Penedès. Trabajos de Prehistoria 71(1), 42-55. doi:10.3989/tp.2014.12123 
Pérez-Jordà, G., Peña-Chocarro, L., Groot, M., Lentjes, D., Zeiler, J., 2013. Agricultural production between the 6th and the 3rd millennium cal BC in the central part of the Valencia region (Spain). Barely Surviving or More Than Enough, 81-100.

Reimer, P.J., Bard, E., Bayliss, A, Beck J.W., Blackwell, P.E., BronkRamsey, C., Groote,s P.M., Guilderson, T.P., Hajdas, I., HattZ, C., Heaton, T.J,. Hoffmann, D.L., Hogg, A.G., Hughen, K.A., Kaiser, K., Kromer, B., Manning, S., Niu, M., Reimer, R.W., Richards, D.A., Scott, E.M., Southon, J.R., Staff, R.A., Turner, C.S.M., van der Plicht, J., 2013. IntCal13 and Marine13 radiocarbon age calibration curves, 0-50.000 years cal BP. Radiocarbon 55(4).

Robertshaw, P.T., 1978. Archaeology of an abandoned pastoralist camp-site. South African Journal of Science 74, 29-31.

Seguí, J.R., 1999. Traditional pastoralism in the Fageca and Famorca villages (Mediterranean Spain): An ethnoarchaeological approach. Archaeology. Phd Universitat de València, Spain.

Rojo, M., Garrido, R., García-Martínez de Lagrán, I., 2012. El Neolítico en la Península Ibérica y su contexto europeo. Cátedra.

Shennan, S., 2013. Demographic Continuities and Discontinuities in Neolithic Europe: Evidence, Methods and Implications. Journal of Archaeological Method and Theory 20 (2), 300-311.

Shennan, S., Downey, S., Timpson, A., Edinborough, K., Colledge, S., Kerig, T., Manning, K., Thomas, M., 2013. Regional population collapse followed initial agricultural booms in midHolocene Europe. Nature Communications DOI: 10.1038/ncomms3486

Timpson, A., Colledge, S., Crema, E., Edinborough, K., Kerig, T., Manning, K., Thomas, M. G., Shennan, S., 2014. Reconstructing regional population fluctuations in the European Neolithic using radiocarbon dates: A new case-study using an improved method. Journal of Archaeological Science, $52,549-557$.

Utrilla. P., Montes, L., 2009. El Mesolítico Geométrico en la península Ibérica. Monografía arqueológia 44. Zaragoza. 
Vaquero, M., García-Argüelles, P., 2009. Algunas reflexiones sobre la ausencia de Mesolítico geométrico en Cataluña. In: Utrilla, P., Montes, L. (coord.), El mesolítico geométrico en la Península Ibérica, Zaragoza, pp. 191-204.

Williams, A.N., 2012. The use of summed radiocarbon probability distributions in archaeology: a review of methods. Journal of Archaeological Science 39 (6), 578-589.

Wood, R., 2015. From revolution to convention: The past, present and future of radiocarbon dating. In Journal of Archaeological Science. Doi: 10.1016/j.jas.2015.02.019.

Zilhão, J., 2001. Radiocarbon evidence for maritime pioneer colonization at the origins of farming in west Mediterranean Europe. Proceedings of the National Academy of Sciences 98, 14180-14185.

\section{Figures}

Table 1. List of radiocarbon dates by materials and regions. SD (standar deviation average).

Figure 1. Map of Iberia with indication of the Mediterranean regions and main sites considered in this work. 1: Husos II; 2: Chaves; 3: Can Sadurní; 4: Guixeres de Vilobí; 5: Barranquet; 6: Cova de 1’Or; 7: Sarsa; 8: Falguera; 9: Mas d’Is; 10: Cendres; 11: Carigüela.

Figure 2. Comparison between SCDPD of Iberia from dates (blue line) and Z standarised dates (red line) (a), and the $\mathrm{Z}$ standarised values by dates (blue line) and sites (red line) (b)-.

Figure 3. Comparison between $\mathrm{Z}$ standarised values by dates (solid line) and sites (dashed line) from selected radiocarbon dates of Iberia (a) with GISP2 ice core (Grootes et al., 1993; Meese et al., 1997) and MD952043 Alboran Sea core (Cacho et al., 1999) (b) and MD99-2343 core of Menorca, (Frigola et al. 2007) (c).

Figure 4. Zsites values by temporal intervals in Northeast, East/Southern, East and Ebro regions. Comparison between $\mathrm{Z}$ standarised values by dates (solid line) and sites (dashed line).

Figure 5. Neolithic sequence in Cova de les Cendres (Moraira, Teulada, Alacant).

Figure 6. Density distributions of different kind of artifacts and resources discarded in Cendres cave. Green bar reflects the density of coprolyts. DensArtf (artifact density), DensCons (resources density), CoproDens (coprolyte density). 


$$
E^{x}
$$




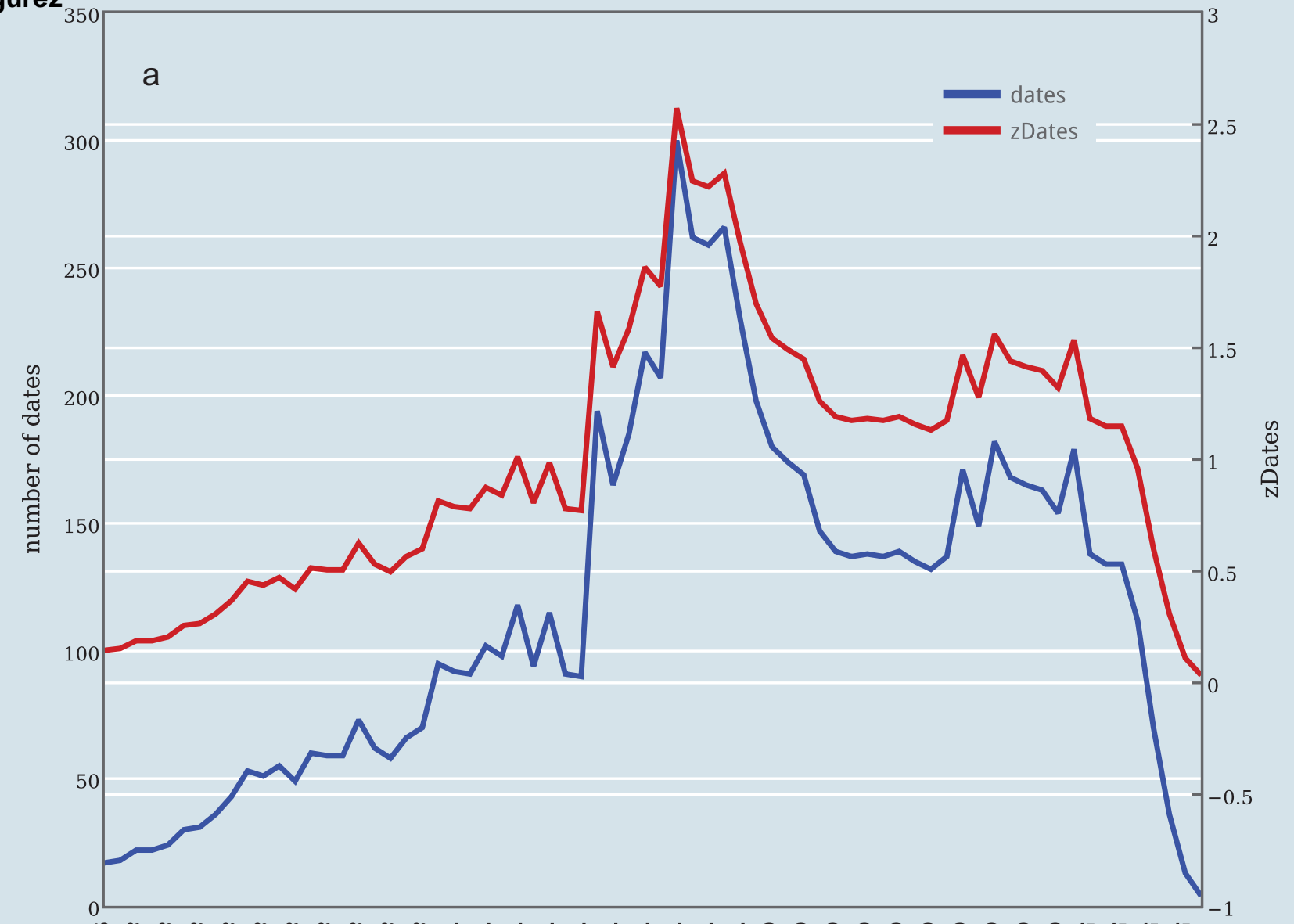

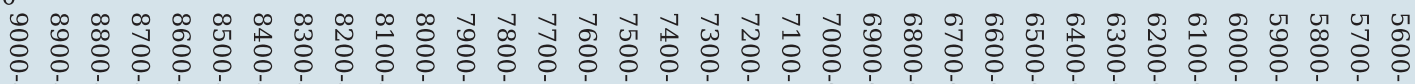

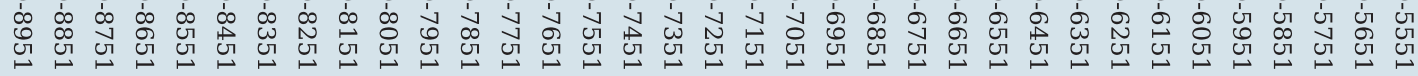

cal age BP

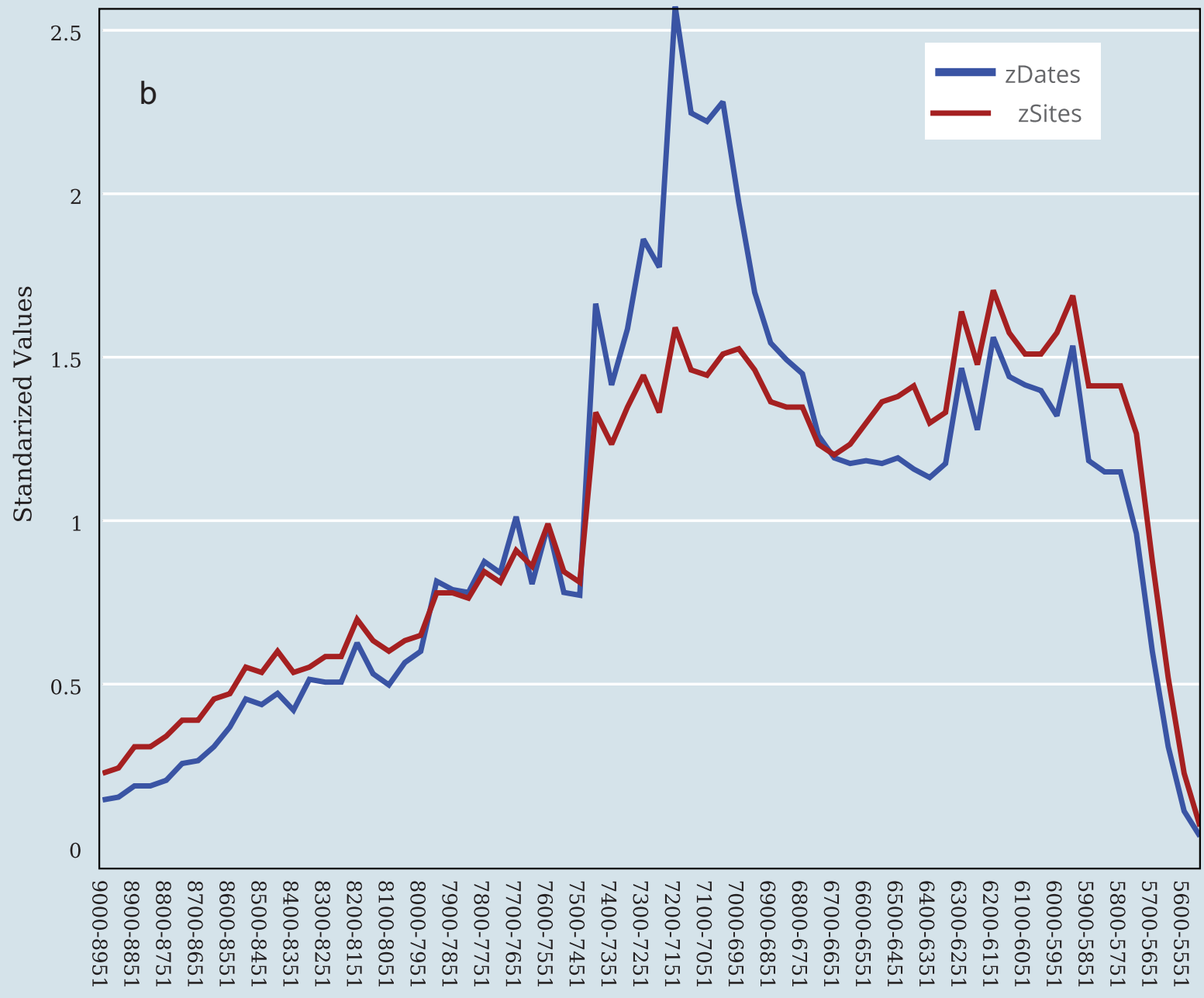


Summed Probability Curves for Radiocarbon Dates and Sites

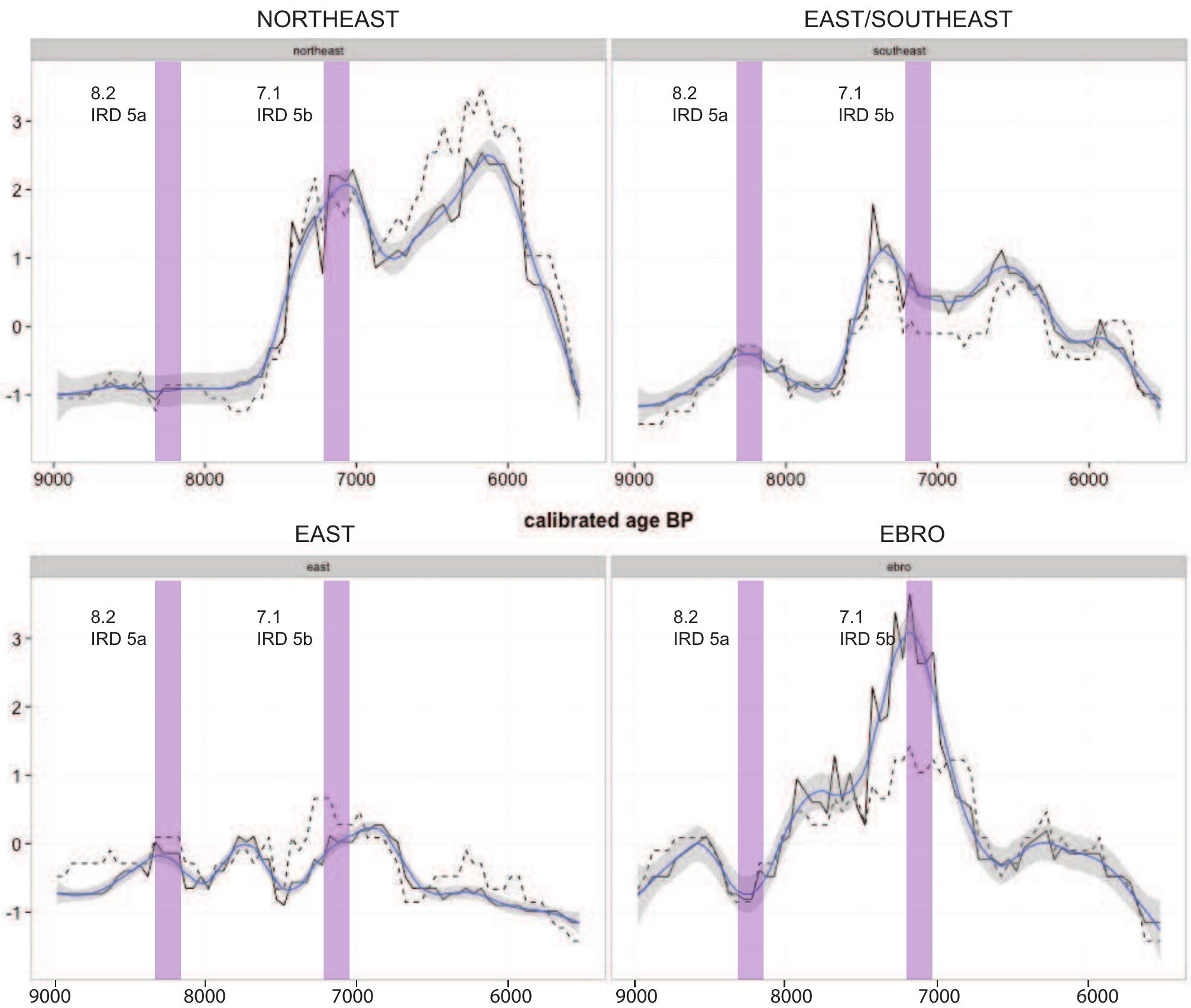




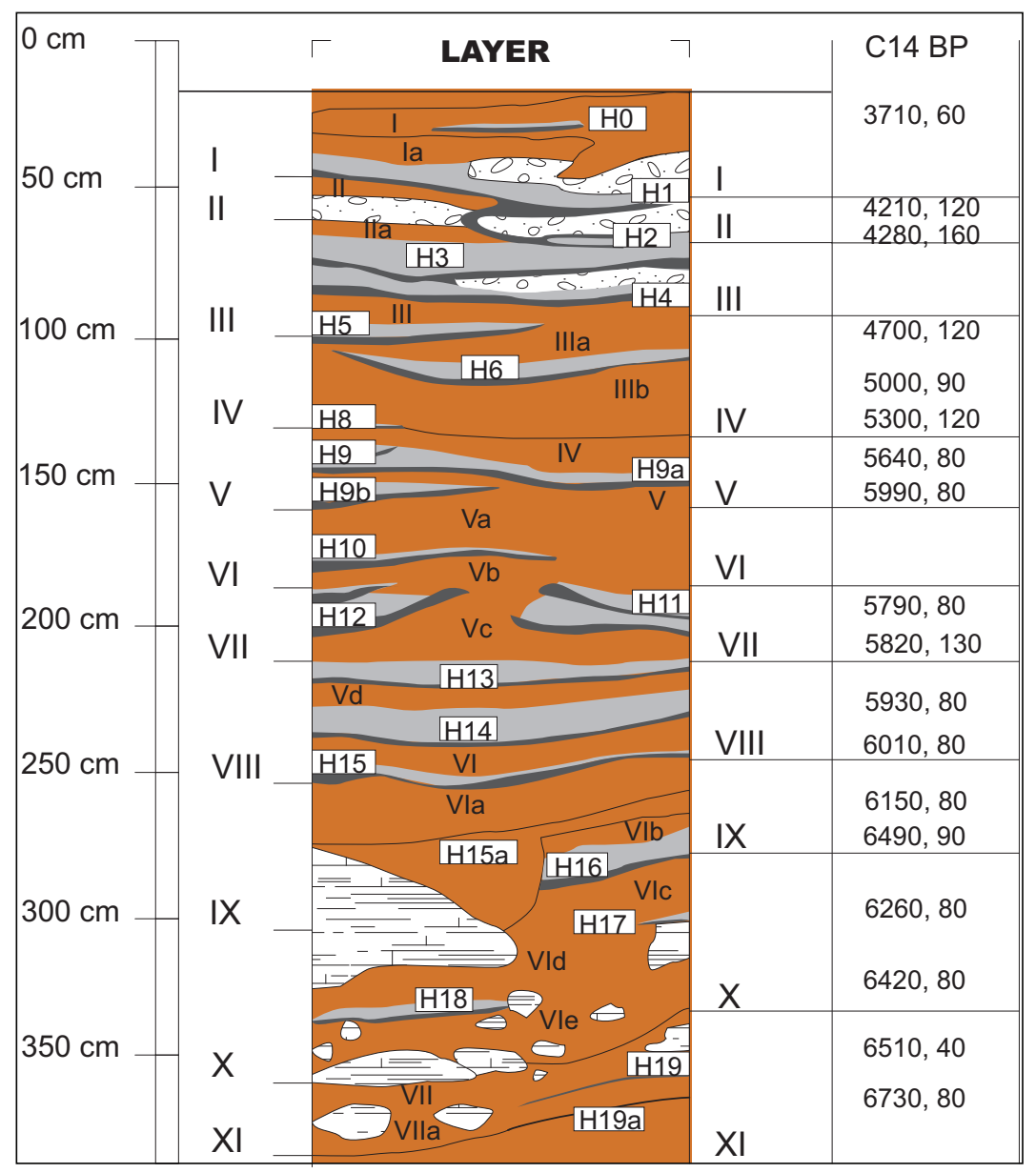




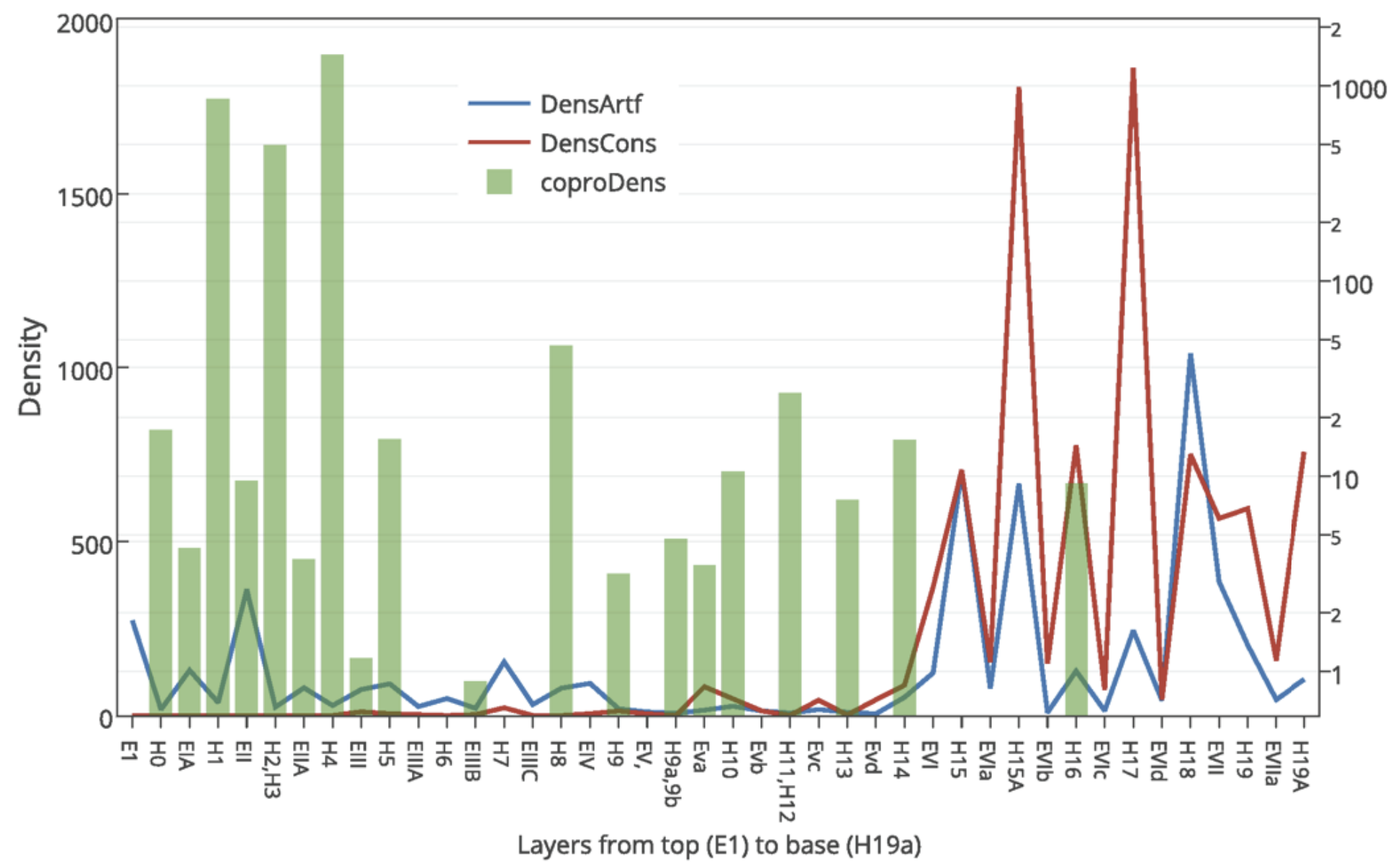




\begin{tabular}{|c|c|c|c|c|c|}
\hline & IBERIA & NORTHEAST & EBRO VALLEY & EAST & EAST/SOUTHEAST \\
\hline All Dates & 1271 & 172 & 195 & 77 & 128 \\
\hline Sites & 359 & 60 & 35 & 18 & 32 \\
\hline Charcoal & 563 & 98 & 82 & 38 & 45 \\
\hline Bone & 410 & 46 & 95 & 35 & 46 \\
\hline Seed/fruit & 131 & 23 & 15 & 4 & 23 \\
\hline Shell & 112 & 0 & 0 & 0 & 6 \\
\hline Other & 22 & 0 & 0 & 0 & 7 \\
\hline Indeterminate & 33 & 5 & 3 & 0 & 1 \\
\hline Dates selected & 1108 & 158 & 186 & 75 & 114 \\
\hline Sites & 324 & 58 & 34 & 18 & 27 \\
\hline SD & 65,8 & 75,1 & 55,4 & 65,1 & 66,8 \\
\hline
\end{tabular}

